\title{
Effect of acid whey-fortified breads on caecal fermentation processes and blood lipid profile in rats
}

\author{
Małgorzata Wronkowska* ${ }^{1 *}$ Maria Soral-Śmietana ${ }^{1}$, Zenon Zduńczyk ${ }^{2}$, Jerzy Juśkiewicz ${ }^{2}$, \\ Monika Jadacka $^{1}$, Anna Majkowska ${ }^{3}$ and Fabian J. Dajnowiec ${ }^{4}$ \\ ${ }^{1}$ Department of Chemistry and Biodynamics of Food, Division of Food Science, Institute of Animal Reproduction and Food \\ Research of the Polish Academy of Sciences, Tuwima 10 Str., 10-748 Olsztyn, Poland \\ ${ }^{2}$ Department of Biological Function of Food, Division of Food Science, Institute of Animal Reproduction and Food Research of \\ the Polish Academy of Sciences, Tuwima 10 Str., 10-748 Olsztyn, Poland \\ ${ }^{3}$ Microbiological Laboratory, Division of Food Science, Institute of Animal Reproduction and Food Research of the \\ Polish Academy of Sciences, Tuwima 10 Str., 10-748 Olsztyn, Poland \\ ${ }^{4}$ Department of Process Engineering and Equipment, Faculty of Food Sciences, University of Warmia and Mazury, \\ M. Oczapowskiego 7 Str., 10-957 Olsztyn, Poland
}

(Submitted 25 October 2016 - Final revision received 23 June 2017 - Accepted 3 July 2017)

\section{Abstract}

Two types of diet - standard and atherogenic - were used to study the effect of wheat or wheat-rye breads supplemented with $20 \%$ acid whey concentrate after ultrafiltration on the physiological response of growing rats. The acid whey concentrate after ultrafiltration used in rat diets caused reduced weight gain (for atherogenic diet with wheat bread); growth of caecum tissue and digesta weight; a decrease in the pH of caecum digesta (for atherogenic diet); reduced activity of bacterial glycolytic enzymes; and a significant increase in total SCFA for both types of diet with wheat-rye breads containing acid whey concentrate. For wheat bread with acid whey, in standard diet, a statistically significant increase was found in the population of bifidobacteria. The results showed that the acid whey concentrates could be used as a valuable food ingredient.

\section{Key words: Acid whey: Ultrafiltration: Bread: In vivo experiments: Rats}

Whey is a product resulting from the technological processes of mature cheese and cottage cheese manufacture. Rennet coagulation of milk is used to produce mature cheese, and the resulting whey is called 'sweet whey' ( $\mathrm{pH}$ from 6.2-6.6). Acid whey is the by-product obtained only after the acid coagulation of milk during the production of cottage cheese or tvarog (with $\mathrm{pH}$ of $4.5-4.7)$. Whey obtained from these two different processes differs in chemical composition and physicochemical properties. Acid whey has more lactic acid, crude ash and less protein as compared with sweet whey ${ }^{(1)}$. Currently, acid whey is mostly wasted or used as animal feed ${ }^{(2)}$. The separation of the liquid part and fractionation of whey solids is now feasible because of the development and implementation of the membrane filtration technique.

Scientists are still looking for food ingredients that would have a positive effect on health and well-being. From our prior investigations, it is known that acid whey contains valuable health components, such as bioactive peptides, lactose and macroelements and microelements ${ }^{(3,4)}$. Bioactive peptides derived from whey proteins, including $\beta$-lactoglobulin, $\alpha$-lactalbumin and serum albumin, have antibacterial properties ${ }^{(5,6)}$, may reduce blood cholesterol level ${ }^{(7)}$ or prevent hypertension ${ }^{(8-10)}$. Mannie \& Asp ${ }^{(11)}$ showed that the introduction of whey to baking products increased their nutritional value. Acid whey after ultrafiltration could be used for improving the nutritional and sensory quality of baking products, as was presented in our previous study ${ }^{(12)}$.

Changes in the gut microbiota associated with high-fat diets and its contribution to the development of metabolic diseases are the main topics of research in many laboratories. It is well known that high-fat diets, such as the Western-type diet, enhance bile secretion to facilitate lipid digestion. Reaching the large bowel, bile acids undergo some modifications by bacteria, thus increasing secondary bile acid production. The most typical secondary bile acid is deoxycholic acid, which is produced from cholic acid. Earlier studies revealed a remarkable effect of cholic acid on gut microbiota populations and their metabolism ${ }^{(3,13)}$. The changes in gut microbiota observed in rats fed a diet supplemented with cholic acid were similar to those observed in mice fed high-fat diets ${ }^{(14,15)}$. The study of Islam et $a{ }^{(16)}$ showed that cholic acid introduced to a rat diet induced phylum-level alterations in the composition of the gut microbiota. They found an increase in the count of Firmicutes and a decrease in the count of Bacteroidetes. Therefore,

* Corresponding author: M. Wronkowska, email m.wronkowska@pan.olsztyn.pl 
we decided to incorporate cholic acid to a high-fat diet in which the main component was bread made with acid whey.

The objective of the present in vivo study was to identify the effects of acid whey-fortified breads on caecal fermentation and blood parameters in growing rats. It was hypothesised that the consumption of breads (wheat or wheat-rye) as the main components of rat diets would be associated with some beneficial changes, including blood lipid profile, caecal microbiota composition and its activity. Two types of diet were used, namely standard diet and cholic acid and cholesterol-supplemented diet (the latter is called atherogenic diet).

\section{Methods}

\section{Materials}

The recipe and technology applied for preparing both types of breads (wheat and wheat-rye) used in this experiment were described in detail by Wronkowska et al. ${ }^{(12)}$. In brief, wheat flour type 750 (Młynomag), tap water, salt and fresh yeast (Lesaffre S.A.) were used for the preparation of wheat bread. Mixed wheat-rye bread was made of a mixture of wheat flour type 750 and rye flour type 720 (3:2, respectively, both flours from Młynomag), tap water, salt and yeast. Acid whey obtained from the industrial production of white fresh cheese (tvarog) was concentrated by ultrafiltration and dehydrated by spray drying. Dried acid whey powder was introduced to the dough as $20 \%$ addition in relation to flour mass. The procedure of acid whey concentration was described by Wronkowska et al. ${ }^{(12)}$. Baked breads after cooling were air-dried, milled and added to the rat diets in powdered form. The following sample abbreviations were used: bread from wheat flour type 750 (W), bread from a mixture of wheat flour type 750 and rye flour type 720 (WR), bread from wheat flour type 750 or from a mixture of wheat flour type 750 and rye flour type 720 with $20 \%$ addition of ultrafiltrated acid whey (WU and WRU).

\section{Preparation of diets and animal protocol}

The animal protocol used in this study was approved by the University of Warmia and Mazury Institutional Animal Care and Use Committee (permission no. 24/2008, Olsztyn, Poland). The experiment was conducted on sixty-four Wistar male rats, aged 4 weeks, weighing about $240 \mathrm{~g}$, randomly divided into experimental groups of eight rats each. The required number of experimental animals was determined for each group according to Berndtson ${ }^{(17)}$.

The animals were housed individually in metal cages under standard conditions: temperature $21-22^{\circ} \mathrm{C}$, relative air humidity $50-70 \%, 12 \mathrm{~h}$ light $-12 \mathrm{~h}$ dark cycle, intensive ventilation (air turnover 10/h) and ad libitum access to water and feed. The nutritional experiment lasted 4 weeks. The composition of experimental diets is presented in Table 1. The content of casein and cellulose was calculated on the basis of the content of protein and carbohydrates in the breads. For the atherogenic diet group, the diet was modified by the addition of lard and cholic acid ( 4 and $0 \cdot 2 \%$ of the diet, respectively), and also by increasing the cholesterol content compared with the standard diet ( $1 v \cdot 0 \cdot 3 \%)$. After the experiment, the rats were anaesthetised with sodium pentobarbital according to the recommendations for euthanasia of experimental animals ${ }^{(18)}$.

Body weight gain and diet intake of rats were determined individually, and the feed conversion ratio (FCR) was calculated as the ratio of diet intake:body weight gain.

After laparotomy, blood samples were taken from the caudal vein and stored in tubes containing heparin. The blood serum was purified by centrifugation at $2500 \mathrm{~g}$ for $15 \mathrm{~min}$ at $4^{\circ} \mathrm{C}$, and stored at $-20^{\circ} \mathrm{C}$ until analysis. The caecum and colon with contents were removed and weighed. Samples of fresh caecum and colon digesta were used for immediate analysis of $\mathrm{DM}, \mathrm{pH}$ (microelectrode and a $\mathrm{pH} / \mathrm{ION}$ meter, model 301; Hanna Instruments), ammonia and SCFA, and the remainder was transferred to tubes and stored at $-20^{\circ} \mathrm{C}$.

The caecal and colonic walls were flushed clean with ice-cold saline, blotted on filter paper and weighed for tissue mass. DM of caecal contents was determined after primary drying at $50-60^{\circ} \mathrm{C}$ for $24 \mathrm{~h}$, with a secondary drying at $105^{\circ} \mathrm{C}$ to determine the constant mass. In fresh caecal digesta, ammonia was extracted and trapped in a solution of boric acid in Conway's dishes, and determined by direct titration with sulphuric acid ${ }^{(19)}$.

Caecal digesta samples were subjected to an SCFA analysis using GC (Shimadzu GC-2010; Shimadzu). The samples (0.2 g) were mixed with $0.2 \mathrm{ml}$ of formic acid, diluted with deionised water and centrifuged at $10000 \mathbf{g}$ for $10 \mathrm{~min}$. The supernatant was loaded onto a capillary column $(30 \mathrm{~m} \times 0.53 \mathrm{~mm}$; BP21; SGE Analytical Science) using an on-column injector. The initial oven temperature was $85^{\circ} \mathrm{C}$, and was raised to $180^{\circ} \mathrm{C}$ by $8^{\circ} \mathrm{C} / \mathrm{min}$ and held for $3 \mathrm{~min}$. The temperatures of the flame ionisation detector and the injection port were 180 and $85^{\circ} \mathrm{C}$, respectively.

Bacterial enzyme activity in the caecal digesta was measured by the rate of $p$ - or $o$-nitrophenol release from nitrophenylglucosides according to the method described by Juśkiewicz et al. ${ }^{(20)}$. The following substrates were used: for $\beta$-glucuronidase, $p$-nitrophenyl- $\beta$-D-glucuronide; for $\alpha$-galactosidase, $p$-nitrophenyl$\alpha$-D-galactopyranoside; for $\beta$-galactosidase, $O$-nitrophenyl- $\beta$-D galactopyranoside; for $\alpha$-glucosidase, $p$-nitrophenyl- $\alpha$-D-glucopyranoside; and for $\beta$-glucosidase, $p$-nitrophenyl- $\beta$-D-glucopyranoside. The reaction mixture contained $0.3 \mathrm{ml}$ of a substrate solution $(5 \mathrm{~mm})$ and $0.2 \mathrm{ml}$ of a $1: 10(\mathrm{v} / \mathrm{v})$ dilution of the caecal sample in $100 \mathrm{~mm}$ phosphate buffer ( $\mathrm{pH} 7 \cdot 0$ ) after centrifugation at $10000 \mathrm{~g}$ for $15 \mathrm{~min}$. Incubation was carried out at $37^{\circ} \mathrm{C}$ and $p$ - or $o$-nitrophenol was quantified at $\lambda=400 \mathrm{~nm}$ and at $\lambda=420 \mathrm{~nm}$, respectively, after addition of $2.5 \mathrm{ml}$ of $0.25 \mathrm{M}$ cold sodium carbonate. The enzymatic activity of $\alpha$ - and $\beta$-glucosidases, $\alpha$ - and $\beta$-galactosidases and $\beta$-glucuronidase was expressed as micromoles of product formed per min (unit) per $1 \mathrm{~g}$ of fresh caecum digesta.

The concentrations of glucose (no. G6620), TAG (no. T6630), total cholesterol (TC) (no. C6608) and HDL-cholesterol fraction (no. H6421) were analysed in the blood serum, using the kits from Alpha Diagnostics Ltd. Log (TAG/HDL-cholesterol) was calculated as an atherogenic index (AI) of serum.

\section{Determination of bacteria in caecum digesta}

Bacteria in caecum digesta were determined according Bielecka et $a l .{ }^{(21)}$. Fresh caecum digesta were immediately homogenised 
with $1 \%$ peptone water as a diluter. After dispersion, the serial decimal dilutions were made avoiding aeration. The live cell number of bifidobacteria was counted on a modified nutrient Garche's agar medium. Coliforms were identified on MacConkey agar. Other microorganisms were quantitatively determined on selective media: Lactobacillus sp., Rogosa Agar (Merck); Enterococcus sp., Bile Aesculin Agar (Merck). The identification of bacteria was based on the appearance of colonies; specific morphology of cells was checked under phase contrast with a Microphot FXA microscope (Nikon).

\section{Statistical analysis}

Results of the physiological response of the treated animals are expressed as means and standard deviations. Statistical comparisons were done transversely among different dietary groups, for standard and atherogenic diets separately. The effects of the two parameters - kind of bread (B), ultrafiltrated whey concentrate (UWC) or their interactions $(\mathrm{B} \times \mathrm{UWC})$ were tested using two-way ANOVA (version 7.1; Statistica). If significance was observed $(P<0 \cdot 05)$, the Duncan's multiplerange test was used to identify differences in the effect of individual diets.

\section{Results and discussion}

Bread is one of the most widely consumed foods in the world. Wheat-rye bread is one of the most popular baking products in Poland. According to the Food and Nutrition Institute ${ }^{(22)}$, different types of bread were proposed in the everyday diet of healthy humans: dark wheat or rye bread (whole wheat or rye) (about $15 \%$ of all eaten breads), white wheat bread (about $20 \%$ of all eaten breads) and mixed rye-wheat bread or light rye bread (should be about $65 \%$ of all eaten breads). Baking products may be one way for the practical use and application of acid whey in the diet. This is why we have proposed in our research to use a spray-dried acid whey concentrate after ultrafiltration as an ingredient in wheat or wheat-rye bread ( $20 \%$ addition in relation to flour mass).

In the in vivo experiment, Wistar male rats were fed for 4 weeks a standard (containing $0.3 \%$ cholesterol) or atherogenic diet ( $1 \%$ cholesterol, $4 \%$ lard and $0.2 \%$ cholic acid). The main component of the diet was wheat or wheat-rye bread, which constituted $77 \%$ of the diet. For both types of diets, standard and atherogenic, the breads without acid whey were used as control (Table 1). Animal models for obesity and other metabolic disorders related to CVD are mostly based on different high-fat and/or high-cholesterol diets that can significantly increase body fat accumulation and/or cause dyslipidaemia of the animals. Many factors, such as the quantity and source of fat used in the diet or the length of experimental feeding, may affect the results obtained in this type of in vivo experiment ${ }^{(23)}$.

For rats fed the standard diet no difference was found in the body weight gain and diet intake (Table 2). However, for rats administered the atherogenic diet a significant effect of

Table 1. Diet composition (\%)

\begin{tabular}{|c|c|c|c|c|c|c|c|c|}
\hline & \multicolumn{4}{|c|}{ W } & \multicolumn{4}{|c|}{ WR } \\
\hline & W & WA & WU & WUA & WR & WRA & WRU & WRUA \\
\hline Bread W & $77 \cdot 0$ & $77 \cdot 0$ & - & - & - & - & - & - \\
\hline Bread WU & - & - & $77 \cdot 0$ & $77 \cdot 0$ & - & - & - & - \\
\hline Bread WR & - & - & - & - & $77 \cdot 0$ & $77 \cdot 0$ & - & - \\
\hline Bread WRU & - & - & - & - & - & - & 77.0 & $77 \cdot 0$ \\
\hline Casein & $6 \cdot 2$ & $6 \cdot 2$ & $6 \cdot 1$ & $6 \cdot 1$ & 8.2 & $8 \cdot 2$ & 8.0 & 8.0 \\
\hline DL-Methionine & 0.3 & 0.3 & 0.3 & 0.3 & 0.3 & 0.3 & 0.3 & 0.3 \\
\hline Soya oil* & 8.0 & 4.0 & 8.0 & 4.0 & 8.0 & 4.0 & 8.0 & 4.0 \\
\hline Lard† & - & 4.0 & - & 4.0 & - & 4.0 & - & 4.0 \\
\hline Cholesterol & 0.3 & 1.0 & 0.3 & 1.0 & 0.3 & 1.0 & 0.3 & 1.0 \\
\hline Cholic acid & - & 0.2 & - & 0.2 & - & 0.2 & - & 0.2 \\
\hline Mineral mix & 3.0 & 3.0 & 3.0 & 3.0 & 3.0 & 3.0 & 3.0 & 3.0 \\
\hline Vitamin mix & 1.0 & 1.0 & 1.0 & 1.0 & 1.0 & 1.0 & 1.0 & 1.0 \\
\hline Maize starch & $2 \cdot 7$ & $1 \cdot 8$ & 2.8 & 1.9 & 0.9 & - & $1 \cdot 1$ & 0.2 \\
\hline Cellulose & 1.5 & 1.5 & 1.5 & 1.5 & 1.3 & 1.3 & 1.3 & $1 \cdot 3$ \\
\hline Total & 100 & 100 & 100 & 100 & 100 & 100 & 100 & 100 \\
\hline \multicolumn{9}{|l|}{ Macronutrients } \\
\hline Carbohydrates & $57 \cdot 7$ & $56 \cdot 8$ & $48 \cdot 8$ & $47 \cdot 9$ & $55 \cdot 6$ & $54 \cdot 7$ & $47 \cdot 1$ & $46 \cdot 2$ \\
\hline Proteins & $18 \cdot 1$ & $18 \cdot 1$ & $18 \cdot 8$ & $18 \cdot 8$ & $18 \cdot 2$ & $18 \cdot 2$ & $18 \cdot 4$ & $18 \cdot 4$ \\
\hline Fats & 9.4 & $10 \cdot 3$ & $9 \cdot 1$ & $10 \cdot 0$ & 9.5 & $10 \cdot 4$ & 9.3 & $10 \cdot 1$ \\
\hline \multicolumn{9}{|l|}{ Fatty acid profile } \\
\hline SFA & 1.47 & 2.65 & 1.42 & $2 \cdot 60$ & 1.47 & $2 \cdot 65$ & 1.45 & 2.63 \\
\hline MUFA & 1.88 & 2.92 & 1.81 & 2.89 & 1.97 & $3 \cdot 01$ & 1.94 & 2.99 \\
\hline PUFA & $5 \cdot 32$ & $3 \cdot 27$ & $5 \cdot 30$ & $3 \cdot 24$ & $5 \cdot 36$ & $3 \cdot 31$ & $5 \cdot 22$ & 3.28 \\
\hline$n-6$ & 4.86 & 3.00 & $4 \cdot 80$ & 2.99 & $4 \cdot 87$ & 3.01 & $4 \cdot 78$ & 3.00 \\
\hline$n-3$ & 0.45 & 0.27 & 0.39 & 0.25 & 0.49 & 0.30 & 0.47 & 0.28 \\
\hline
\end{tabular}

W, bread from wheat flour type 750; WR, bread from mixture of wheat flour type 750 and rye flour type 720 (3:2); WU and WRU, bread from wheat flour type 750 and from mixture of wheat flour type 750 and rye flour type 720 with $20 \%$ addition of acid whey concentrated by ultrafiltration and dehydrated by spray drying; WA, WUA, WRA and WRUA, atherogenic diet with bread W, WR, WU and WRU.

${ }^{*}$ Fatty acid profile: C16:0 (12.1\%); C18:0 (4.1\%); C18:1 n-9 (22.1\%); C18:2 n-6 (55.4\%); C18:3 n-3 (5.3\%); C20:0 (0.4\%); C22:0 (0.5\%).

† Fatty acid profile: C14:0 (1.6\%); C16:0 (28.1\%); C18:0 (14.2\%); C18:1 n-9 (48.2\%); C18:2 n-6 (8.9\%); C18:3 n-3 (0.6\%); C20:0 (2.2\%). 
Table 2. Body weight gain and diet intake of rats fed the experimental diets (Mean values and standard deviations; $n$ 8)

\begin{tabular}{|c|c|c|c|c|c|c|c|c|}
\hline & \multicolumn{2}{|c|}{ Initial body weight (g) } & \multicolumn{2}{|c|}{ Body weight gain (g) } & \multicolumn{2}{|c|}{ Diet intake (g) } & \multicolumn{2}{|c|}{ FCR } \\
\hline & Mean & SD & Mean & SD & Mean & SD & Mean & SD \\
\hline \multicolumn{9}{|l|}{ Standard diets } \\
\hline W & 243.0 & 9.0 & $116 \cdot 4$ & $19 \cdot 8$ & 547.6 & $25 \cdot 0$ & $4 \cdot 79$ & 0.64 \\
\hline WU & 242.8 & 9.6 & 112.2 & 13.1 & 543.8 & 19.2 & 4.90 & 0.58 \\
\hline WR & $242 \cdot 4$ & 9.2 & 109.6 & 13.0 & 544.5 & $22 \cdot 6$ & 5.04 & 0.78 \\
\hline WRU & 242.9 & $9 \cdot 3$ & 104.2 & $10 \cdot 7$ & 533.7 & $20 \cdot 4$ & $5 \cdot 16$ & 0.45 \\
\hline ANOVA & & & & & & & & \\
\hline B & \multicolumn{2}{|c|}{ NS } & \multicolumn{2}{|c|}{ NS } & \multicolumn{2}{|c|}{ NS } & \multicolumn{2}{|c|}{ NS } \\
\hline UWC & \multicolumn{2}{|c|}{ NS } & \multicolumn{2}{|c|}{ NS } & \multicolumn{2}{|c|}{ NS } & \multicolumn{2}{|c|}{ NS } \\
\hline$B \times U W C$ & \multicolumn{2}{|c|}{ NS } & \multicolumn{2}{|c|}{ NS } & \multicolumn{2}{|c|}{ NS } & \multicolumn{2}{|c|}{ NS } \\
\hline \multicolumn{9}{|c|}{ Atherogenic diets } \\
\hline WA & $242 \cdot 6$ & $10 \cdot 1$ & $122 \cdot 2^{A}$ & 8.5 & 559.5 & 24.4 & 4.59 & 0.35 \\
\hline WUA & 242.5 & 8.7 & $105 \cdot 2^{\mathrm{B}}$ & 13.9 & $527 \cdot 2$ & 24.9 & 5.08 & 0.66 \\
\hline WRA & $242 \cdot 3$ & 9.8 & $105 \cdot 2^{\mathrm{B}}$ & 11.9 & $521 \cdot 7$ & $15 \cdot 2$ & $5 \cdot 01$ & 0.53 \\
\hline WRUA & 242.5 & 8.7 & $99 \cdot 3^{\mathrm{B}}$ & 13.5 & $518 \cdot 2$ & $20 \cdot 2$ & 5.23 & 0.60 \\
\hline \multicolumn{9}{|l|}{ ANOVA } \\
\hline B & \multicolumn{2}{|c|}{ NS } & \multicolumn{2}{|c|}{ 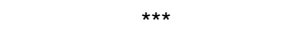 } & \multicolumn{2}{|c|}{ NS } & \multicolumn{2}{|c|}{ NS } \\
\hline UWC & \multicolumn{2}{|c|}{ NS } & \multicolumn{2}{|c|}{$\star \star \star \star ~$} & \multicolumn{2}{|c|}{ NS } & \multicolumn{2}{|c|}{ NS } \\
\hline$B \times U W C$ & \multicolumn{2}{|c|}{ NS } & \multicolumn{2}{|c|}{ NS } & \multicolumn{2}{|c|}{ NS } & \multicolumn{2}{|c|}{ NS } \\
\hline
\end{tabular}

FCR, feed conversion ratio; W, bread from wheat flour type 750; WR, bread from mixture of wheat flour type 750 and rye flour type 720 (3:2); WU and WRU, bread from wheat flour type 750 and from mixture of wheat flour type 750 and rye flour type 720 with $20 \%$ addition of acid whey concentrated by ultrafiltration and dehydrated by spray drying; WA, WUA, WRA and WRUA, atherogenic diet with bread W, WR, WU and WRU.

A,B Mean values within a column with unlike superscript letters were significantly different $(P<0.05)$ in Duncan's test.

*** Significant effects by kind of bread (B), ultrafiltrated whey concentrate (UWC) or their interactions $(\mathrm{B} \times \mathrm{UWC})$ at $P<0.05$.

bread kind and acid whey concentrate used was observed. A significant decrease of body weight gain was noticed for rats fed the bread with $20 \%$ addition of acid whey concentrated by ultrafiltration. It should be noted, however, that diet intake for all diets, standard and atherogenic, was almost the same. The FCR for all diets containing acid whey was higher compared with the control diet with only wheat or wheat-rye bread, but these results were not statistically significant. Tranberg et al. ${ }^{(24,25)}$ found that whey reduced early weight gain in high-fat-fed young mice, but they also showed that whey had an acute but not chronic effect on weight gain. For healthy aged rats an increase of whey protein intake was effective in slowing lean body mass loss ${ }^{(26)}$. Kopeć et al. ${ }^{(27)}$ showed that the body weight gain was significantly higher in rats fed bread with sourdough and whey proteins compared with control diets. In turn, Masarwi et $a l^{(28)}$ suggested that in growing male rats whey protein led to slower bone growth with reduced weight gain compared with casein protein. Whey protein isolate and a free amino acid mixture simulating the amino acid composition of the whey protein isolate had a similar effect on satiety of normal-weight women as presented by Chungchunlam et al. ${ }^{(29)}$. Wright $e t a l .^{(30)}$ did not find an influence of 9-month whey protein supplementation on bone quantity (bone mineral density or content) in overweight and obese adults.

In the case of the standard diets, there were no differences in the parameters analysed for the small intestine, as the mass and $\mathrm{pH}$ of digesta were not affected by the type of bread used (Table 3). However, results obtained for the atherogenic diets showed that the addition of acid whey to wheat bread caused a significant increase in small intestinal mass. In addition, acid whey in the diet significantly decreased the $\mathrm{pH}$ of small intestinal digesta in rats fed both types of bread.
Acid whey concentrate after ultrafiltration significantly increased the mass of caecal tissues and digesta in rats fed either the standard or atherogenic diets (Table 3). Control wheat-rye bread in the standard diet significantly decreased the $\mathrm{pH}$ of the caecal and colon digesta, whereas in the case of the atherogenic diets a significant decrease in the $\mathrm{pH}$ of caecal digesta was found for rats fed diets with acid whey concentrate. Generally, $\mathrm{pH}$ of colon digesta was not related to the type of diet used. Only for the WRU diet was a significant increase in colon $\mathrm{pH}$ observed compared with the WR diet. The ammonia level in caecal digesta did not change under the influence of acid whey. This effect is beneficial because, as shown by Nousiainen ${ }^{(31)}$, ammonia can destroy cells and reduce villus height and once absorbed must be excreted as urea with the loss of energy. When quark was used as an ingredient of rat diets a significant decrease of caecal $\mathrm{pH}$ value and caecal ammonia concentration was observed by Juśkiewicz et al. ${ }^{(32)}$. The acidification of caecal digesta for rats fed the atherogenic diet with acid whey can be considered a beneficial influence of acid whey on fermentative processes in the hind gut ${ }^{(33)}$.

The enzyme activity determined in the caecal digesta is presented in Table 4. Generally, for both types of diets a decrease was found in the activity of all analysed enzymes as affected by acid whey concentrate. This effect was more pronounced for diets with wheat bread than for those with wheat-rye bread. Jurgoński et al. ${ }^{(34)}$ found that a decrease in enzyme activity could indicate a reduction in the content of easily fermentable components in the caecum. In the standard diet, acid whey concentrate caused no reduction in $\beta$-galactosidase activity, but in the atherogenic diet it suppressed $\beta$-galactosidase activity. As shown previously, breads with acid whey are a good source of lactose ${ }^{(12)}$. According to the literature, lactose that is undigested and unabsorbed in the small 
Table 3. Gastrointestinal tract parameters of rats fed the experimental diets

(Mean values and standard deviations; $n 8$ )

\begin{tabular}{|c|c|c|c|c|c|c|c|c|c|c|c|c|c|c|c|c|c|c|c|c|}
\hline & \multicolumn{4}{|c|}{ Small intestine } & \multicolumn{10}{|c|}{ Caecum } & \multicolumn{6}{|c|}{ Colon } \\
\hline & \multicolumn{2}{|c|}{$\begin{array}{c}\text { Full mass } \\
\text { (g/100 g BW) }\end{array}$} & \multicolumn{2}{|c|}{$\mathrm{pH}$} & \multicolumn{2}{|c|}{$\begin{array}{c}\text { Tissues } \\
\text { (g/100 BW) }\end{array}$} & \multicolumn{2}{|c|}{$\begin{array}{c}\text { Digesta } \\
\text { (g/100 BW) } \\
\end{array}$} & \multicolumn{2}{|c|}{$\mathrm{pH}$} & \multicolumn{2}{|c|}{ DM of digesta (\%) } & \multicolumn{2}{|c|}{$\begin{array}{c}\text { Ammonia } \\
\text { (mg/g digesta) }\end{array}$} & \multicolumn{2}{|c|}{$\begin{array}{c}\text { Tissues } \\
\text { (g/100 BW) }\end{array}$} & \multicolumn{2}{|c|}{$\begin{array}{c}\text { Digesta } \\
\text { (g/100 BW) }\end{array}$} & \multicolumn{2}{|c|}{$\mathrm{pH}$} \\
\hline & Mean & SD & Mean & SD & Mean & SD & Mean & SD & Mean & SD & Mean & SD & Mean & SD & Mean & SD & Mean & SD & Mean & SD \\
\hline \multicolumn{21}{|l|}{ Standard diets } \\
\hline W & $2 \cdot 20$ & 0.22 & $7 \cdot 13$ & 0.38 & $0.30^{c}$ & 0.04 & $0.99^{\mathrm{c}}$ & 0.17 & $6 \cdot 73^{\mathrm{a}}$ & 0.15 & $19 \cdot 75^{\mathrm{a}}$ & 1.53 & 0.25 & 0.07 & 0.33 & 0.06 & $0.29^{\mathrm{b}}$ & 0.08 & $6 \cdot 72^{\mathrm{a}}$ & 0.27 \\
\hline WU & $2 \cdot 24$ & 0.19 & 6.98 & 0.23 & $0.35^{\mathrm{b}}$ & 0.04 & $1.39^{\mathrm{b}}$ & 0.19 & $6.59^{\mathrm{a}}$ & 0.22 & $17.64^{b}$ & 1.05 & 0.25 & 0.02 & 0.36 & 0.03 & $0.46^{\mathrm{a}}$ & 0.06 & $6.67^{a}$ & 0.20 \\
\hline WR & $2 \cdot 37$ & 0.15 & 7.31 & 0.46 & $0.39^{a, b}$ & 0.05 & $1.50^{\mathrm{b}}$ & 0.27 & $6 \cdot 12^{\mathrm{c}}$ & 0.12 & $16.03^{\mathrm{c}}$ & 1.39 & 0.26 & 0.04 & 0.35 & 0.03 & $0.44^{\mathrm{a}}$ & 0.17 & $6 \cdot 11^{\mathrm{C}}$ & 0.13 \\
\hline WRU & $2 \cdot 32$ & 0.22 & $7 \cdot 29$ & 0.17 & $0.43^{\mathrm{a}}$ & 0.04 & $1.96^{\mathrm{a}}$ & 0.26 & $6 \cdot 31^{\mathrm{b}}$ & 0.17 & $16 \cdot 56^{\mathrm{b}, \mathrm{c}}$ & 1.93 & 0.25 & 0.05 & 0.38 & 0.05 & $0.44^{\mathrm{a}}$ & 0.10 & $6 \cdot 44^{\mathrm{b}}$ & 0.21 \\
\hline ANOVA & \multirow{2}{*}{\multicolumn{4}{|c|}{ NS }} & \multirow{2}{*}{\multicolumn{2}{|c|}{$\star \star \star *$}} & & & & & & & & & & & & & & \\
\hline B & & & & & & & ** & & \multicolumn{2}{|c|}{$\star \star \star *$} & $* * \star$ & & \multicolumn{2}{|c|}{ NS } & $\mathrm{N}$ & & \multicolumn{2}{|c|}{ NS } & \multicolumn{2}{|c|}{$* \star *$} \\
\hline UWC & \multicolumn{2}{|c|}{ NS } & $\mathrm{N}$ & & \multirow{2}{*}{\multicolumn{2}{|c|}{$* * *$}} & ** & & \multicolumn{2}{|c|}{ NS } & NS & & \multirow{2}{*}{\multicolumn{2}{|c|}{ NS }} & $\mathrm{N}$ & & \multirow{2}{*}{\multicolumn{2}{|c|}{$* * *$}} & \multicolumn{2}{|c|}{ NS } \\
\hline$B \times U W C$ & \multicolumn{2}{|c|}{ NS } & $\mathrm{N}$ & & \multirow{2}{*}{\multicolumn{2}{|c|}{ NS }} & $\mathrm{N}$ & & ** & & $* * \star$ & & & & $\mathrm{N}$ & & & & & \\
\hline Atherogenic di & & & & & & & & & & & & & & & & & & & & \\
\hline WA & $2 \cdot 38^{\mathrm{B}}$ & 0.21 & $7 \cdot 24^{\mathrm{B}}$ & 0.15 & $0.37^{\mathrm{C}}$ & 0.04 & $1.43^{\mathrm{C}}$ & 0.20 & $6 \cdot 31^{A}$ & 0.18 & $17.95^{\mathrm{A}}$ & 1.32 & 0.27 & 0.04 & $0.35^{\mathrm{B}}$ & 0.07 & $0.42^{\mathrm{B}}$ & 0.08 & $6 \cdot 31$ & 0.26 \\
\hline WUA & $2 \cdot 64^{\mathrm{A}}$ & 0.27 & $6.86^{\mathrm{C}}$ & 0.24 & $0.53^{\mathrm{A}}$ & 0.08 & $2 \cdot 80^{\mathrm{B}}$ & 0.41 & $5 \cdot 97^{\mathrm{B}, \mathrm{C}}$ & 0.28 & $16 \cdot 81^{\mathrm{A}, \mathrm{B}}$ & 1.26 & 0.28 & 0.07 & $0.43^{\mathrm{A}}$ & 0.05 & $0.58^{\mathrm{A}}$ & 0.11 & $6 \cdot 25$ & 0.31 \\
\hline WRA & $2.65^{\mathrm{A}}$ & 0.17 & $7.46^{\mathrm{A}}$ & 0.15 & $0.47^{B}$ & 0.06 & $2 \cdot 65^{\mathrm{B}}$ & 0.59 & $6 \cdot 08^{B}$ & 0.16 & $15 \cdot 50^{\mathrm{B}}$ & $1 \cdot 17$ & 0.27 & 0.03 & $0.41^{\mathrm{A}}$ & 0.04 & $0.63^{\mathrm{A}}$ & 0.15 & 6.09 & 0.17 \\
\hline WRUA & $2.83^{\mathrm{A}}$ & 0.18 & $6 \cdot 94^{C}$ & 0.28 & $0.59^{A}$ & 0.04 & $3.44^{\mathrm{A}}$ & 0.34 & $5 \cdot 84^{C}$ & 0.21 & $15 \cdot 85^{\mathrm{B}}$ & 2.06 & 0.28 & 0.03 & $0.39^{\mathrm{A}, \mathrm{B}}$ & 0.04 & $0.52^{\mathrm{A}, \mathrm{B}}$ & 0.12 & $6 \cdot 11$ & 0.25 \\
\hline ANOVA & & & & & & & & & & & & & & & & & & & & \\
\hline B & & & $\mathrm{N}$ & & $* \star *$ & & ** & & ** & & $* * \star$ & & & & $\mathrm{N}$ & & $\mathrm{NS}$ & & & \\
\hline UWC & & & ** & & $* \star \star *$ & & ** & & ** & & NS & & & & $\mathrm{N}$ & & Ns & & $\Lambda$ & \\
\hline$B \times U W C$ & & & $\mathrm{~N}$ & & NS & & $\mathrm{Ns}$ & & $\mathrm{N}$ & & NS & & & & ** & & $* *$ & & $\Lambda$ & \\
\hline
\end{tabular}

BW, body weight; $W$, bread from wheat flour type 750; WR, bread from mixture of wheat flour type 750 and rye flour type 720 (3:2); WU and WRU, bread from wheat flour type 750 and from mixture of wheat flour type 750 and rye flour type 720 with $20 \%$ addition of acid whey concentrated by ultrafiltration and dehydrated by spray drying; WA, WUA, WRA and WRUA, atherogenic diet with bread W, WR, WU and WRU.

*** Significant effects by kind of bread (B), ultrafiltrated whey concentrate (UWC) or their interactions $(\mathrm{B} \times \mathrm{UWC})$ at $P<0.05$. 
Table 4. Bacterial enzyme activity in the caecum digesta (Mean values and standard deviations; $n$ )

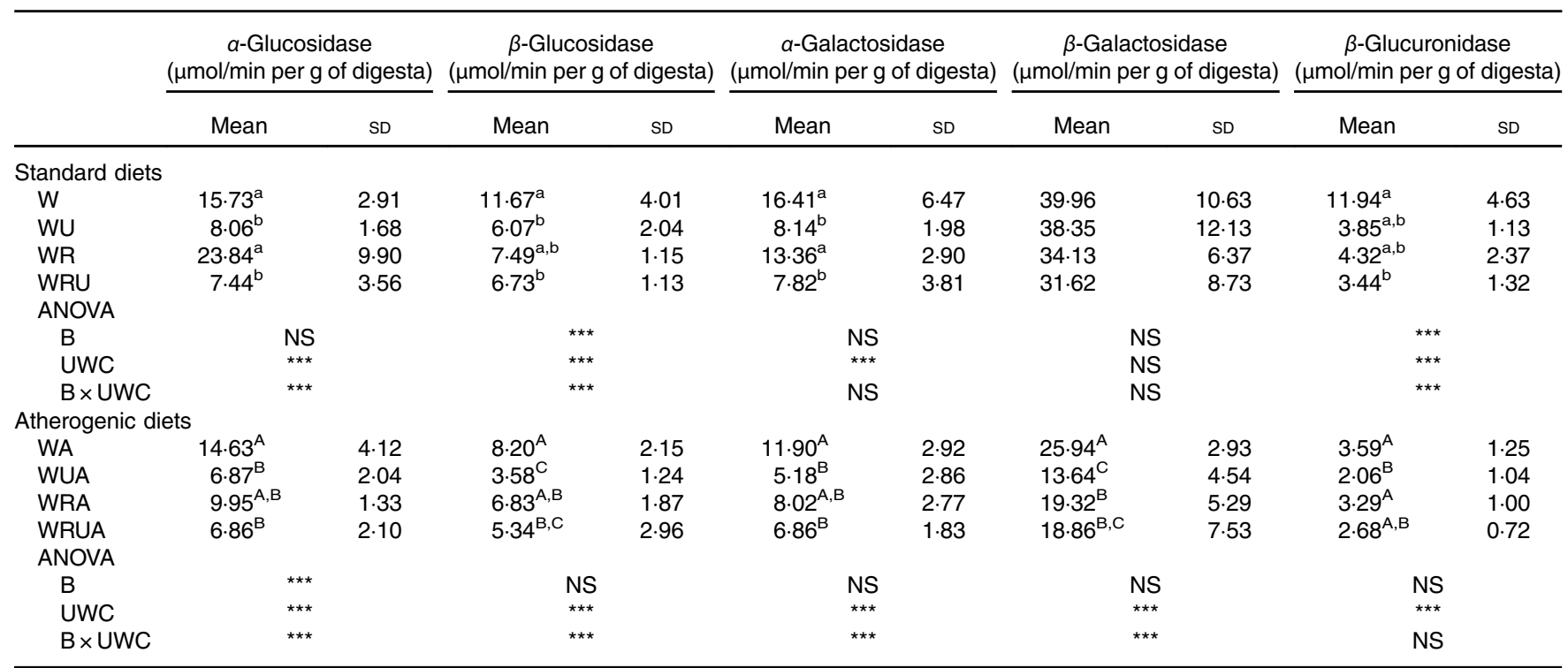

W, bread from wheat flour type 750; WR, bread from mixture of wheat flour type 750 and rye flour type 720 (3:2); WU and WRU, bread from wheat flour type 750 and from mixture of wheat flour type 750 and rye flour type 720 with $20 \%$ addition of acid whey concentrated by ultrafiltration and dehydrated by spray drying; WA, WUA, WRA and WRUA, atherogenic diet with bread W, WR, WU and WRU.

$\mathrm{A}, \mathrm{B}, \mathrm{C}, \mathrm{a}, \mathrm{b}$ Mean values within a column with unlike superscript letters were significantly different $(P<0.05)$ in Duncan's test.

${ }^{\star * \star}$ Significant effects by kind of bread (B), ultrafiltrated whey concentrate (UWC) or their interactions $(\mathrm{B} \times \mathrm{UWC})$ at $P<0.05$.

intestine passes into the colon, where in large part it is used as a substrate for microbial anaerobic digestion, and its residues are excreted with faeces ${ }^{(35)}$. Juśkiewicz et al. ${ }^{(32)}$ found an increase in the activity of $\beta$-galactosidase in the caecal digesta of rats fed quark, which could indicate improved use of lactose that is not digested in the upper parts of the gastrointestinal tract. The suppressed activity of $\beta$-galactosidase after the administration of the atherogenic diet with whey concentrate may indicate a lower content of undigested lactose reaching the caecum. This could confirm the hypothesis that for high-fat diets lactose is used in larger amounts in the upper parts of the gastrointestinal tract ${ }^{36-38)}$. Special attention should be paid to the potentially adverse activity of enzymes, such as $\beta$-glucuronidase. The level of $\beta$-glucuronidase activity is a marker of pathogenic microflora activity leading to metabolic changes in a pro-carcinogenic direction. Bacterial $\beta$-glucuronidase is able to release toxins, drugs and steroids, previously bound in the liver with glucuronic acid. A decrease in $\beta$-glucuronidase activity caused by the addition of acid whey concentrates to the bread should be considered as a positive effect for consumer health ${ }^{(39)}$.

Generally, acid whey concentrate after ultrafiltration used in the standard rat diet increased the total content of SCFA in caecum digesta (Table 5). In the case of the atherogenic diet, the increase in total SCFA content was statistically significant only for wheat-rye bread with acid whey. Particularly noteworthy is the significant increase of butyric acid content as a result of incorporation of the acid whey concentrate after ultrafiltration. Breads used in this study were a source of lactose ${ }^{(12)}$, which could be a substrate for intestinal microflora. The final bacterial metabolites of lactose fermentation are the SCFA (mainly acetic, propionic and butyric acids) and gas ( $\mathrm{H}$, carbon dioxide). Thus, the higher concentration of SCFA observed for the diet with bread with acid whey concentrate after ultrafiltration in relation to the control group could result from increased contents of protein and lactose in the analysed breads, and these components could be used as potential substrates for intestinal microbiota ${ }^{(35,40)}$.

For rats fed the atherogenic diets, the total SCFA concentrations in caecal digesta were only about half of those observed in rats fed the standard diets. Literature data demonstrate that fat enhances the absorption of lactose and carbohydrate by slowing gastric emptying and elongating intestinal transit ${ }^{(36-38,40)}$. This leads to prolonged contact of lactase with the intestinal contents and with lactose. This could be the reason for the lower total content of SCFA observed for the atherogenic groups compared with the standard groups. Juśkiewicz et al. ${ }^{(32)}$ found no changes in total SCFA content in rats fed a diet containing quark compared with the standard diet, and only a significant decrease in propionic acid concentration was observed for that group.

Biochemical indices in blood serum of rats fed the experimental diets are shown in Table 6. A statistically nonsignificant decrease was observed in serum glucose and TAG levels of rats fed both types of diet with wheat bread fortified by acid whey concentrate. Only the TC concentrations in blood serum of rats fed the atherogenic diets differed significantly. Introduction of acid whey into these diets caused a significant increase of TC. There was no effect of experimental diets on the AI value. Juśkiewicz et $a l{ }^{(32)}$ studied the physiological effect of quark produced with or without transglutaminase in growing rats, and reported that quark produced with transglutaminase exerted more favourable modifications to serum cholesterol levels, as well as $\mathrm{Ca}$ and $\mathrm{P}$ utilisation, compared with quark produced without this enzyme. Formigoni et al. ${ }^{(41)}$ found a lowering of plasma glucose concentrations for pigs fed liquid whey. A diet with 
Table 5. Concentration and profile of SCFA in the caecum digesta (Mean values and standard deviations; $n$ 8)

\begin{tabular}{|c|c|c|c|c|c|c|c|c|c|c|c|c|c|c|c|c|c|c|c|c|}
\hline & \multicolumn{2}{|c|}{$\begin{array}{c}\text { Acetic acid } \\
(\mu \mathrm{mol} / \mathrm{g} \text { of digesta })\end{array}$} & \multicolumn{2}{|c|}{$\begin{array}{l}\text { Propionic acid } \\
\text { ( } \mu \mathrm{mol} / \mathrm{g} \text { of } \\
\text { digesta) }\end{array}$} & \multicolumn{2}{|c|}{$\begin{array}{l}\text { Iso-butyric acid } \\
\text { ( } \mu \mathrm{mol} / \mathrm{g} \text { of } \\
\text { digesta) }\end{array}$} & \multicolumn{2}{|c|}{$\begin{array}{l}\text { Butyric acid } \\
\text { ( } \mu \mathrm{mol} / \mathrm{g} \text { of } \\
\text { digesta) }\end{array}$} & \multicolumn{2}{|c|}{$\begin{array}{l}\text { Iso-valeric acid } \\
\text { ( } \mu \mathrm{mol} / \mathrm{g} \text { of } \\
\text { digesta) }\end{array}$} & \multicolumn{2}{|c|}{$\begin{array}{l}\text { Valeric acid } \\
\text { ( } \mu \mathrm{mol} / \mathrm{g} \text { of } \\
\text { digesta) }\end{array}$} & \multicolumn{2}{|c|}{$\begin{array}{l}\text { Total SCFA } \\
\text { ( } \mu \mathrm{mol} / \mathrm{g} \text { of } \\
\text { digesta) }\end{array}$} & \multicolumn{2}{|c|}{$\begin{array}{l}\text { C2 Profile } \\
\text { (\% of total } \\
\text { SCFA) }\end{array}$} & \multicolumn{2}{|c|}{$\begin{array}{l}\text { C3 Profile } \\
\text { (\% of total } \\
\text { SCFA) }\end{array}$} & \multicolumn{2}{|c|}{$\begin{array}{l}\text { C4 Profile } \\
\text { (\% of total } \\
\text { SCFA) }\end{array}$} \\
\hline & Mean & SD & Mean & SD & Mean & SD & Mean & SD & Mean & SD & Mean & SD & Mean & SD & Mean & SD & Mean & SD & Mean & SD \\
\hline \multicolumn{21}{|l|}{ Standard diets } \\
\hline W & $51 \cdot 12^{a}$ & $13 \cdot 79$ & $16 \cdot 78$ & 4.59 & $0.23^{a, b}$ & 0.05 & $4.55^{b}$ & 0.78 & 0.20 & $0 \cdot 12$ & $0.74^{\mathrm{a}}$ & 0.32 & $73 \cdot 6^{a, b}$ & $16 \cdot 1$ & $68 \cdot 60^{\mathrm{a}}$ & 6.86 & $23 \cdot 18^{b}$ & 5.01 & $6.54^{\mathrm{b}}$ & $2 \cdot 27$ \\
\hline WU & $54.73^{\mathrm{a}}$ & $10 \cdot 42$ & $16 \cdot 27$ & 2.38 & $0.27^{\mathrm{a}}$ & 0.06 & $10 \cdot 69^{\mathrm{a}}$ & 2.65 & 0.28 & 0.08 & $0.79^{a}$ & 0.14 & $83 \cdot 0^{\mathrm{a}}$ & $12 \cdot 2$ & $65 \cdot 60^{a, b}$ & 3.95 & $19 \cdot 80^{b}$ & $2 \cdot 86$ & $12 \cdot 96^{\mathrm{a}}$ & 2.77 \\
\hline WR & $36 \cdot 69^{b}$ & 9.04 & 18.47 & $2 \cdot 98$ & $0.15^{\mathrm{c}}$ & 0.11 & $4 \cdot 37^{b}$ & $2 \cdot 32$ & 0.21 & 0.19 & $0.37^{b}$ & 0.14 & $60 \cdot 3^{\mathrm{b}}$ & $12 \cdot 6$ & $60 \cdot 46^{\mathrm{b}}$ & $3 \cdot 12$ & $31 \cdot 18^{a}$ & 4.02 & $7 \cdot 06^{b}$ & $2 \cdot 80$ \\
\hline WRU & $50 \cdot 62^{a}$ & 11.92 & $15 \cdot 50$ & 4.13 & $0.17^{b, c}$ & 0.05 & $10 \cdot 47^{\mathrm{a}}$ & 5.03 & 0.19 & 0.07 & $0.48^{\mathrm{b}}$ & 0.19 & $77 \cdot 4^{\mathrm{a}}$ & $15 \cdot 2$ & $65 \cdot 05^{a, b}$ & $6 \cdot 16$ & $20 \cdot 37^{b}$ & 5.66 & $13.49^{\mathrm{a}}$ & 5.74 \\
\hline ANOVA & \multirow{2}{*}{\multicolumn{4}{|c|}{ 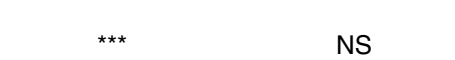 }} & \multirow{2}{*}{\multicolumn{2}{|c|}{ *** }} & & & & & & & & & & & & & & \\
\hline B & & & & & & & NS & & \multicolumn{2}{|c|}{ NS } & * & & \multicolumn{2}{|c|}{ NS } & 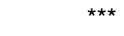 & & \multicolumn{2}{|l|}{$\star \star \star *$} & \multicolumn{2}{|c|}{ NS } \\
\hline UWC & \multicolumn{2}{|c|}{$* * *$} & \multicolumn{2}{|l|}{ NS } & \multirow{2}{*}{\multicolumn{2}{|c|}{ NS }} & $* * *$ & & \multirow{2}{*}{\multicolumn{2}{|c|}{$\begin{array}{l}\text { NS } \\
\text { NS }\end{array}$}} & $\mathrm{N}$ & & \multirow{2}{*}{\multicolumn{2}{|c|}{$\begin{array}{l}\star \star \star * \\
N S\end{array}$}} & NS & & \multirow{2}{*}{\multicolumn{2}{|c|}{$\begin{array}{l}* \star * \\
\star * *\end{array}$}} & \multirow{2}{*}{\multicolumn{2}{|c|}{$\begin{array}{l}\star \star \star * \\
N S\end{array}$}} \\
\hline$B \times U W C$ & & & \multicolumn{2}{|l|}{ NS } & & & \multicolumn{2}{|l|}{ NS } & & & \multicolumn{2}{|c|}{ NS } & & & NS & & & & & \\
\hline \multicolumn{3}{|c|}{ Atherogenic diets } & & & \multicolumn{2}{|c|}{ INo } & & & & & & & & & & & & & & \\
\hline WA & $29 \cdot 22^{A}$ & 4.69 & $16 \cdot 34^{\mathrm{B}}$ & 2.57 & 0.17 & 0.06 & $1.65^{\mathrm{A}, \mathrm{B}}$ & 0.49 & 0.21 & $0 \cdot 12$ & 0.06 & 0.06 & $47.6^{\mathrm{A}}$ & $5 \cdot 1$ & $61.09^{A}$ & $5 \cdot 18$ & $34.44^{\mathrm{B}}$ & 5.07 & 3.53 & 1.33 \\
\hline WUA & $28.94^{\mathrm{A}}$ & 7.73 & $16 \cdot 74^{\mathrm{B}}$ & 4.01 & 0.13 & 0.05 & $1.77^{\mathrm{A}}$ & 0.82 & 0.24 & 0.11 & 0.09 & 0.11 & $47.9^{\mathrm{A}}$ & $9 \cdot 3$ & $60.06^{\mathrm{A}}$ & 7.57 & $35 \cdot 38^{B}$ & 7.98 & 3.59 & 1.33 \\
\hline WRA & $18.93^{B}$ & 4.28 & $18.04^{\mathrm{A}, \mathrm{B}}$ & 2.58 & 0.14 & 0.04 & $0.90^{C}$ & 0.85 & 0.20 & 0.08 & 0.04 & 0.02 & $38.2^{\mathrm{B}}$ & $6 \cdot 7$ & $49 \cdot 11^{\mathrm{A}, \mathrm{B}}$ & 2.86 & $47.55^{\mathrm{A}}$ & 3.94 & $2 \cdot 30$ & 2.02 \\
\hline WRUA & $24.22^{\mathrm{A}, \mathrm{B}}$ & 4.52 & $21.73^{\mathrm{A}}$ & 5.07 & 0.14 & 0.05 & $1.07^{\mathrm{B}, \mathrm{C}}$ & 0.38 & 0.20 & 0.08 & 0.06 & 0.05 & $47 \cdot 4^{\mathrm{A}}$ & 8.9 & $51 \cdot 15^{\mathrm{B}}$ & 2.90 & $45.54^{\mathrm{A}}$ & 3.57 & 2.41 & $1 \cdot 16$ \\
\hline ANOVA & & & & & & & & & & & & & & & & & & & & \\
\hline B & & & *** & & & & $* \star *$ & & & & $\mathrm{~N}$ & & NS & & *** & & *** & & NS & \\
\hline UWC & & & NS & & & & NS & & & & $\mathrm{N}$ & & NS & & NS & & NS & & NS & \\
\hline$B \times U W C$ & & & NS & & & & NS & & & & $\mathrm{N}$ & & 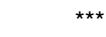 & & NS & & NS & & NS & \\
\hline
\end{tabular}

W, bread from wheat flour type 750 ; WR, bread from mixture of wheat flour type 750 and rye flour type 720 (3:2); WU and WRU, bread from wheat flour type 750 and from mixture of wheat flour type 750 and rye flour type 720 with $20 \%$ addition of acid whey concentrated by ultrafiltration and dehydrated by spray drying; WA, WUA, WRA and WRUA, atherogenic diet with bread W, WR, WU and WRU.

*** Significant effects by kind of bread (B), ultrafiltrated whey concentrate (UWC) or their interactions (B $\times$ UWC) at $P<0.05$ 
Table 6. Biochemical indices in blood serum of rats fed the experimental diets

(Mean values and standard deviations; $n$ )

\begin{tabular}{|c|c|c|c|c|c|c|c|c|c|c|c|c|}
\hline & \multicolumn{2}{|c|}{ Glucose $(\mathrm{mmol} / \mathrm{l})$} & \multicolumn{2}{|c|}{ TAG (mmol/l) } & \multicolumn{2}{|c|}{$\mathrm{TC}(\mathrm{mmol} / \mathrm{l})$} & \multicolumn{2}{|c|}{ HDL-TC (mmol/l) } & \multicolumn{2}{|c|}{ HDL-TC (\% TC) } & \multicolumn{2}{|c|}{$\mathrm{Al}$} \\
\hline & Mean & SD & Mean & SD & Mean & SD & Mean & SD & Mean & SD & Mean & SD \\
\hline \multicolumn{13}{|l|}{ Standard diets } \\
\hline W & $7 \cdot 36$ & 0.62 & 1.46 & 0.27 & 1.97 & 0.05 & 1.05 & 0.11 & 53.19 & 5.87 & 0.90 & 0.21 \\
\hline WU & 7.29 & 0.90 & 1.02 & 0.26 & 2.09 & 0.32 & 1.04 & 0.09 & 50.07 & $4 \cdot 31$ & 1.01 & 0.18 \\
\hline WR & 7.08 & 0.19 & 1.35 & 0.32 & 1.82 & 0.11 & 0.98 & 0.15 & 53.30 & 5.49 & 0.89 & 0.21 \\
\hline WRU & 7.36 & 0.22 & 1.06 & 0.28 & 1.82 & 0.36 & 0.97 & 0.24 & 53.39 & 5.54 & 0.89 & 0.17 \\
\hline ANOVA & & & & & & & & & & & & \\
\hline B & \multicolumn{2}{|c|}{ NS } & \multicolumn{2}{|c|}{ NS } & \multicolumn{2}{|c|}{ NS } & \multicolumn{2}{|c|}{ NS } & \multicolumn{2}{|c|}{ NS } & \multicolumn{2}{|c|}{ NS } \\
\hline UWC & \multicolumn{2}{|c|}{ NS } & \multicolumn{2}{|c|}{ NS } & \multicolumn{2}{|c|}{ NS } & \multicolumn{2}{|c|}{ NS } & \multicolumn{2}{|c|}{ NS } & \multicolumn{2}{|c|}{ NS } \\
\hline $\mathrm{B} \times \mathrm{UWC}$ & \multicolumn{2}{|c|}{ NS } & & & \multicolumn{2}{|c|}{ NS } & \multicolumn{2}{|c|}{ NS } & & & \multicolumn{2}{|c|}{ NS } \\
\hline \multicolumn{13}{|l|}{ Atherogenic diets } \\
\hline WA & $7 \cdot 80$ & 0.93 & 1.00 & 0.23 & $3.59^{A, B}$ & 0.97 & 0.96 & 0.10 & 28.06 & 5.08 & 2.67 & 0.65 \\
\hline WUA & 7.05 & 0.66 & 0.81 & 0.34 & $3.98^{\mathrm{A}}$ & 0.49 & 1.14 & 0.32 & 28.27 & $6 \cdot 30$ & $2 \cdot 70$ & 0.83 \\
\hline WRA & 7.01 & 0.77 & 0.88 & 0.23 & $2 \cdot 84^{\mathrm{B}}$ & 0.38 & 0.96 & 0.14 & 35.02 & $9 \cdot 81$ & 2.03 & 0.73 \\
\hline WRUA & 7.74 & 0.93 & 0.74 & 0.18 & $3 \cdot 19^{\mathrm{A}, \mathrm{B}}$ & 0.47 & 1.03 & 0.10 & 32.42 & $2 \cdot 26$ & $2 \cdot 10$ & 0.21 \\
\hline \multicolumn{13}{|l|}{ ANOVA } \\
\hline B & \multicolumn{2}{|c|}{ NS } & \multicolumn{2}{|c|}{ NS } & \multicolumn{2}{|c|}{$* * *$} & \multicolumn{2}{|c|}{ NS } & \multicolumn{2}{|c|}{ NS } & \multicolumn{2}{|c|}{ NS } \\
\hline UWC & \multicolumn{2}{|c|}{ NS } & \multicolumn{2}{|c|}{ NS } & & & & & & & & \\
\hline$B \times U W C$ & & & & & $\Lambda$ & & & & & & & \\
\hline
\end{tabular}

TC, total cholesterol; HDL-TC, HDL fraction of total cholesterol; Al, atherogenic index (TC-HDL/HDL); W, bread from wheat flour type 750; WR, bread from mixture of wheat flour type 750 and rye flour type 720 (3:2); WU and WRU, bread from wheat flour type 750 and from mixture of wheat flour type 750 and rye flour type 720 with $20 \%$ addition of acid whey concentrated by ultrafiltration and dehydrated by spray drying; WA, WUA, WRA and WRUA, atherogenic diet with bread W, WR, WU and WRU.

A,B Mean values within a column with unlike superscript letters were significantly different $(P<0.05)$ in Duncan's test.

*** Significant effects by kind of bread (B), ultrafiltrated whey concentrate (UWC) or their interactions $(\mathrm{B} \times \mathrm{UWC})$ at $P<0.05$.

Table 7. Effect of experimental diets on caecum microbiota populations

(Mean values and standard deviations; $n$ )

\begin{tabular}{|c|c|c|c|c|c|c|c|c|}
\hline & \multicolumn{2}{|c|}{$\begin{array}{c}\text { Lactobacillus } \\
\text { (log CFU/g of digesta) }\end{array}$} & \multicolumn{2}{|c|}{$\begin{array}{c}\text { Bifidobacterium } \\
\text { (log CFU/g of digesta) }\end{array}$} & \multicolumn{2}{|c|}{$\begin{array}{c}\text { Coliforms } \\
\text { (log CFU/g of digesta) }\end{array}$} & \multicolumn{2}{|c|}{$\begin{array}{c}\text { Enterococcus } \\
\text { (log CFU/g of digesta) }\end{array}$} \\
\hline & Mean & SD & Mean & SD & Mean & SD & Mean & SD \\
\hline \multicolumn{9}{|l|}{ Standard diets } \\
\hline W & $8 \cdot 80$ & 0.61 & $8 \cdot 54^{c}$ & 0.51 & $6 \cdot 73$ & $1 \cdot 24$ & 6.89 & 0.13 \\
\hline WU & 8.92 & 0.33 & $9 \cdot 61^{a}$ & 0.52 & 6.55 & $1 \cdot 11$ & $6 \cdot 66$ & 0.34 \\
\hline WR & 9.00 & 0.33 & $9 \cdot 08^{\mathrm{b}}$ & 0.43 & $7 \cdot 21$ & 1.42 & $7 \cdot 07$ & 0.49 \\
\hline WRU & $8 \cdot 76$ & 0.33 & $9 \cdot 43^{a, b}$ & 0.28 & $5 \cdot 81$ & 1.62 & $6 \cdot 73$ & 0.35 \\
\hline \multicolumn{9}{|l|}{ ANOVA } \\
\hline B & \multicolumn{2}{|c|}{ NS } & \multicolumn{2}{|c|}{ NS } & \multicolumn{2}{|c|}{ NS } & \multicolumn{2}{|c|}{ NS } \\
\hline UWC & \multicolumn{2}{|c|}{ NS } & \multicolumn{2}{|c|}{$\star * *$} & \multicolumn{2}{|c|}{ NS } & \multicolumn{2}{|c|}{ NS } \\
\hline$B \times U W C$ & \multicolumn{2}{|c|}{ NS } & \multicolumn{2}{|c|}{$* \star \star$} & \multicolumn{2}{|c|}{ NS } & \multicolumn{2}{|c|}{ NS } \\
\hline \multicolumn{9}{|c|}{ Atherogenic diets } \\
\hline WA & 8.58 & 0.22 & 8.55 & 0.34 & 7.96 & 0.54 & $6 \cdot 76$ & 0.29 \\
\hline WUA & $8 \cdot 71$ & 0.35 & 8.77 & 0.50 & $8 \cdot 30$ & 1.09 & $6 \cdot 76$ & 0.34 \\
\hline WRA & $8 \cdot 32$ & 0.64 & 8.45 & 0.36 & $8 \cdot 34$ & 0.60 & $6 \cdot 92$ & 0.40 \\
\hline WRUA & 8.54 & 0.79 & $8 \cdot 86$ & 0.65 & 8.63 & 0.59 & $6 \cdot 67$ & 0.49 \\
\hline \multicolumn{9}{|l|}{ ANOVA } \\
\hline B & \multicolumn{2}{|c|}{ NS } & \multicolumn{2}{|c|}{ NS } & \multicolumn{2}{|c|}{ NS } & \multicolumn{2}{|c|}{ NS } \\
\hline UWC & \multicolumn{2}{|c|}{ NS } & \multicolumn{2}{|c|}{ NS } & \multicolumn{2}{|c|}{ NS } & \multicolumn{2}{|c|}{ NS } \\
\hline$B \times U W C$ & \multicolumn{2}{|c|}{ NS } & \multicolumn{2}{|c|}{ NS } & \multicolumn{2}{|c|}{ NS } & \multicolumn{2}{|c|}{ NS } \\
\hline
\end{tabular}

CFU, colony-forming units; W, bread from wheat flour type 750; WR, bread from mixture of wheat flour type 750 and rye flour type 720 (3:2); WU and WRU, bread from wheat flour type 750 and from mixture of wheat flour type 750 and rye flour type 720 with $20 \%$ addition of acid whey concentrated by ultrafiltration and dehydrated by spray drying; WA, WUA, WRA and WRUA, atherogenic diet with bread W, WR, WU and WRU.

a,b,c Mean values within a column with unlike superscript letters were significantly different $(P<0.05)$ in Duncan's test.

*** Significant effects by kind of bread (B), ultrafiltrated whey concentrate (UWC) or their interactions $(\mathrm{B} \times \mathrm{UWC})$ at $P<0.05$.

whey protein supplements administered to rats reduced liver lipid content but only when lipids were increased with a highcholesterol diet as presented by Nagaoka et al. ${ }^{(42)}$. In humans, a decrease of postprandial blood glucose levels under the influence of whey protein was observed by Petersen et al. ${ }^{(43)}$.
The content of selected groups of bacteria in rats caecum digesta was analysed and the results are presented in Table 7. Acid whey concentrate after ultrafiltration caused favourable, but not statistically confirmed, growth of lactobacilli and bifidobacteria. Only for the standard diet with wheat bread fortified with acid whey was a 
statistically significant increase of bifidobacteria observed. The counts of Enterococcus and coliforms decreased, insignificantly, for the standard diets with acid whey concentrate. However, for the atherogenic diets with acid whey concentrate, a statistically insignificant increase was found in the count of coliforms. Wronkowska et $a l .{ }^{(12)}$ showed that wheat and wheat-rye bread supplemented with $20 \%$ acid whey concentrate after ultrafiltration were sources of lactose. Lactose that is undigested and unabsorbed from the small intestine could be used as a substrate for anaerobic microbial fermentation in the colon ${ }^{(35)}$

A high-fat diet seems to be strongly involved in the phylogenic changes of gut microbiota composition in obese individuals, probably because of the overflow of dietary fat to the distal intestine ${ }^{(44,45)}$. Costabile et $a l^{(46)}$ found a significant increase in bifidobacteria count after in vitro fermentation (with human faeces) of bread produced using a sourdough process compared with breads produced with yeasted dough.

\section{Summary}

The effect of wheat or wheat-rye breads supplemented with $20 \%$ of acid whey concentrate after ultrafiltration on the physiological response of growing rats was studied. Generally, the acid whey concentrate used in both types of bread had a more positive influence on rats fed the atherogenic diet compared with standard diets. A significant decrease in body weight gain and an increase in small intestinal mass were observed for rats fed the atherogenic diet with wheat bread supplemented by acid whey. For the atherogenic diets with acid whey concentrate, a significant decrease was found in caecal digesta $\mathrm{pH}$. In addition, for the highfat diet, a significant decrease in the activity of $\beta$-glucuronidase caused by the addition of acid whey concentrate should be considered as a positive effect for consumer health. Generally, acid whey concentrate after ultrafiltration increases the total content of caecal digesta SCFA. The significant increase in butyric acid content as a result of incorporation of the acid whey concentrate after ultrafiltration is particularly noteworthy. Advantageous effects of both types of bread with the acid whey concentrate used in the standard diet were confirmed by the increase in the population of bifidobacteria.

\section{Acknowledgements}

The authors thank the National Centre for Research and Development in Poland for financial support (grant no. 2P06T 01129). M. W., M. S.-Ś, Z. Z., J. J., M. J., A. M. and F. J. D. participated in the realisation of this grant.

M. S.-Ś. managed the grant and all authors had full access to all the data in the study and take responsibility for the integrity of the data and the accuracy of analyses. M. S.-S. and Z. Z. were involved in the conception and design of the study. A. M. designed and performed microbiological analyses. F. J. D. designed and prepared acid whey concentrate. M. W and J. J. were involved in the collection and assembly of data, and the analysis and interpretation of the data. J. J. and M. J. performed the statistical analyses. M. J. was involved in carrying out most of the chemical analyses. Critical revision of the manuscript for important intellectual content was completed by all the authors. This research was used as a part of the $\mathrm{PhD}$ thesis of $\mathrm{M}$. J.

The authors declare that there are no conflicts of interest.

\section{References}

1. Jelen P (2003) Whey processing: utilization and products. In Encyclopedia of Dairy Sciences, pp. 2739-2745 [H Roginski, JW Fuquay and PF Fox, editors]. New York: Academic Press.

2. Konrad G, Kleinschmidt T \& Faber W (2012) Ultrafiltration flux of acid whey obtained by lactic acid fermentation. Int Dairy J 2, 73-77.

3. Wronkowska M, Soral-Śmietana M, Zander L, et al. (2012) The moulding of technological properties and quality of bread by adding industrially produced concentrate of acid-whey obtained during the making of cottage cheese. Żywn Nauk Technol Ja $\mathbf{2}$, 56-67 (English abstract).

4. Soral-Śmietana M, Zduńczyk Z, Wronkowska M, et al. (2013) Mineral composition and bioavailability of calcium and phosphorus from acid-whey concentrated by various membrane processes. J. Elem 18, 115-125.

5. Pellegrini A, Dettling C, Thomas U, et al. (2001) Isolation and characterization of four bactericidal domains in bovine $\beta$-lactoglobulin. Biochim Biophys Acta 1526, 131-140.

6. Pellegrini A (2003) Antimicrobial peptides from food proteins. Curr Pharm Des 9, 1225-1238.

7. Nagaoka S, Futamura Y, Miwa K, et al. (2001) Identification of novel hypocholesterolemic peptides derived from bovine milk $\beta$-lactoglobulin. Biochem Biophys Res Commun 281, 11-17.

8. Morris PE \& Fitzgerald RJ (2008) Whey proteins and peptides in human health. In Whey Processing, Functionality and Health Benefits, pp. 285-384 [ChI Onwulata and PJ Huth, editors]. New York: Wiley-Blackwell, IFT Press.

9. Smithers GW (2008) Whey and whey proteins - From 'gutter-to-gold'. Int Dairy J 18, 695-704.

10. Pal S, Ellis V \& Ho S (2010) Acute effects of whey protein isolate on cardiovascular risk factors in overweight, post-menopausal women. Atherosclerosis 212, 339-344.

11. Mannie E \& Asp EH (1999) Dairy ingredients for bread baking. Cereal Food World 44, 143-146.

12. Wronkowska M, Jadacka M, Soral-Śmietana M, et al. (2015) Acid whey concentrated by ultrafiltration a tool for modeling bread properties. LWT - Food Sci Technol 61, 172-176.

13. Turnbaugh PJ, Ridaura VK, Faith JJ, et al. (2009) The effect of diet on the human gut microbiome: a metagenomic analysis in humanized gnotobiotic mice. Sci Transl Med 1, 6-14.

14. Turnbaugh PJ, Bäckhed F, Fulton L, et al. (2008) Diet-induced obesity is linked to marked but reversible alterations in the mouse distal gut microbiome. Cell Host Microbe 3, 213-223.

15. Murphy EF, Cotter PD, Healy S, et al. (2010) Composition and energy harvesting capacity of the gut microbiota: relationship to diet, obesity and time in mouse models. Gut 59, 1635-1642.

16. Islam KB, Fukiya S, Hagio M, et al. (2011) Bile acid is a host factor that regulates the composition of the cecal microbiota in rats. Gastroenterology 141, 1773-1781.

17. Berndtson WE (1991) A simple, rapid and reliable method for selecting or assessing the number of replicates for animal experiments. J Anim Sci 69, 67-76.

18. Close B, Banister K, Baumans V, et al. (1997) Recommendation for euthanasia of experimental animals: part 2. Lab Anim 31, $1-32$.

19. Hofirek B \& Haas D (2001) Comparative studies of ruminal fluid collected by stomach tube or by puncture of the caudoventral ruminal sac. Sac Acta Vet Brno 70, 27-33.

20. Juśkiewicz J, Zduńczyk Z, Wróblewska M, et al. (2003) Influence of oligosaccharide extract from pea and lupin 
seeds on caecal fermentation in rats. I Anim Feed Sci $\mathbf{1 2}$, 289-298.

21. Bielecka M, Biedrzycka E, Majkowska A, et al. (2002) Effect of non-digestible oligosaccharides on gut microecosystem in rats. Food Res Int 35, 139-144.

22. Food and Nutritional Institute (2017) The principles of proper nutrition. http://www.izz.waw.pl/pl/zasady-prawidowego-ywienia (accessed April 2017)

23. Hariri N \& Thibault L (2010) High-fat diet-induced obesity in animal models. Nutr Res Rev 23, 270-299.

24. Tranberg B, Hellgren LI, Lykkesfeldt J, et al. (2013) Whey protein reduces early life weight gain in mice fed a high-fat diet. PLOS ONE 8, e71439.

25. Tranberg B, Madsen AN, Hansen AK, et al. (2015) Whey-reduced weight gain is associated with a temporary growth reduction in young mice fed a high-fat diet. J Nutr Biochem 26, 9-15.

26. Mosoni L, Gatineau E, Gatellier P, et al. (2014) High whey protein intake delayed the loss of lean body mass in healthy old rats, whereas protein type and polyphenol/antioxidant supplementation had no effects. PLOS ONE 9, e109098.

27. Kopeć A, Borczak B, Pysz M, et al. (2014) An addition of sourdough and whey proteins affects the nutritional quality of wholemeal wheat bread. Acta Sci Pol Technol Aliment 13, 43-54.

28. Masarwi M, Gabet Y, Dolkart O, et al. (2016) Skeletal effect of casein and whey protein intake during catch-up growth in young male Sprague-Dawley rats. Br J Nutr 116, 59-69.

29. Chungchunlam SMS, Henare SJ, Ganesh S, et al. (2016) Effect of whey protein and free amino acid mixture simulating whey protein on measures of satiety in normal-weight women. $\mathrm{BrJ}$ Nutr 116, 1666-1673.

30. Wright CS, McMorrow AM, Weinheimer-Haus EM, et al. (2017) Whey protein supplementation and higher total protein intake do not influence bone quantity in overweight and obese adults following a 36-week exercise and diet intervention. J Nutr 1, 179-186.

31. Nousiainen J (1991) Comparative observations on selected probiotics and olaquindox as feed additives for piglets around weaning. 2. Effect on villus length and crypt depth in the jejunum, ileum, caecum and colon. J Anim Physiol Anim Nutr 66, 224-230.

32. Juśkiewicz J, Zduńczyk Z, Bohdziewicz K, et al. (2012) Physiological effects of the dietary application of quark produced with enzyme transglutaminase as a sole protein source in growing rats. Int Dairy J 26, 155-161.

33. Kosmala M, Kołodziejczyk K, Zduńczyk Z, et al. (2011) Chemical composition of natural and polyphenol-free apple pomace and the effect of this dietary ingredient on intestinal fermentation and serum lipid parameters in rats. J Agric Food Chem 59, 9177-9185.

34. Jurgoński A, Juśkiewicz J, Sójka M, et al. (2008) Black currant seeds after supercritical carbon dioxide extraction as a potential dietary supplement. Roczniki Państw Zakt Hig 59, 421-427 (English abstract).

35. Vonk RJ, Reckman GAR, Harmsen HJM, et al. (2012) Probiotics and lactose intolerance. In Probiotics, pp. 149-160 [E Rigobelo, editor]. Rijeka, Croatia: IN TECH d.o.o. http://www.intechopen. com/books/probiotics/probiotics-and-lactose-intolerance

36. Spiller RC, Trotman IF, Higgins BE, et al. (1984) The ileal brake-inhibition of jejunal motility after ileal fat perfusion in man. Gut 25, 365-374.

37. Holgate AM \& Read NW (1985) Effect of ileal infusion of intralipid on gastrointestinal transit, ileal flow rate, and carbohydrate absorption in humans after ingestion of a liquid meal. Gastroenterology 88, 1005-1011.

38. Houghton LA, Mangnall YF \& Read NW (1990) Effect of incorporating fat into a liquid test meal on the relation between intragastric distribution and gastrin emptying in human volunteers. Gut 31, 1226-1229.

39. Wróblewska M, Juśkiewicz J \& Wiczkowski W (2011) Physiological properties of beetroot crisps applied in standard and dyslipidemic diets for rats. Lipids Health Dis 10, 178-185.

40. He T, Venema K, Priebe MG, et al. (2008) The role of colonic metabolism in lactose intolerance. Eur J Clin Invest 38, 541-547.

41. Formigoni A, Piva A, Pezzi P, et al. (2006) The influence of feeding fresh liquid whey on some blood metabolites, insulin, and cecal fermentations of growing pigs. Anim Feed Sci Technol 131, 52-65.

42. Nagaoka S, Kanamaru Y \& Kuzuya Y (1991) Effects of whey-protein and casein on the plasma and liver lipids in rats. Agric Biol Chem 55, 813-818.

43. Petersen BL, Ward LS, Bastian ED, et al. (2009) A whey protein supplement decreases post-prandial glycemia. Nutr J 8, 47-51.

44. Delzenne NM \& Cani PD (2011) Interaction between obesity and the gut microbiota: Relevance in nutrition. Annu Rev Nutr 31, 15-31.

45. De Wit N, Derrien M, Bosch-Vermeulen H, et al. (2012) Saturated fat stimulates obesity and hepatic steatosis and affects gut microbiota composition by an enhanced overflow of dietary fat to the distal intestine. Am J Physiol Gastrointest Liver Physiol 303, 589-599.

46. Costabile A, Santarelli S, Claus SP, et al. (2014) Effect of breadmaking process on in vitro gut microbiota parameters in irritable bowel syndrome. PLOS ONE 9, e111225. 